\title{
INFLUENCE OF SOLAR RADIATION TO THE TEMPERATURE INSIDE A THREE-LAYER PARTITION IN WINTER SEASON
}

\author{
Patrycja Antonik-Popiołek \\ Faculty of Materials, Civil and Environmental Engineering, University of Bielsko-Biala, Bielsko-Biała, Poland
}

\begin{abstract}
The article presents an analysis of the impact of solar radiation on the temperature changes in the external three-layer partition of a smart building. Data for analysis were taken from temperature sensors located in individual layers of the wall and from a weather station on the roof of a building. The data were recorded $24 \mathrm{~h}$ in 5- and 15-minute intervals. The analysis period was one month in a winter season. The purpose of the analysis was to determine the correlation between the solar radiation measured as the illuminance and the temperature inside the wall. In the analysed period of one month the correlation was very weak. Also, considering only the illuminance over 10,000 lx, the correlation was noticeable, but still very weak. The use of innovative fiber optic technology with fibre Bragg grating was proposed to avoid incorrect measurements.
\end{abstract}

Key words: outside wall, solar radiation, temperature, smart building

\section{INTRODUCTION}

Speed of wind, external temperature, solar radiation, air humidity and precipitation are the basic meteorological climate-forming factors. All those factors can influence on the temperature inside the wall. Is there a correlation between the solar radiation and temperature in the external wall? The paper presents an analysis of solar radiation impact on temperature in an external wall. There are a few publications which describe methods used to investigate the temperature distribution and changes in walls or at their surface. Climate-forming factors were analysed in many other papers. The influence of wind and evaporation to the thermal transmittance was considered by Cui, Xie and Xue (2019). Ahola and Lahdensivu (2017) presented an analysis of the temperature inside a building where the internal temperature is not regulated. The analysis was conducted by means of numerical methods and concerned the heat flow within the wall affected by external temperature fluctuations. Temperature distribution in a wall may be also studied using a thermal imaging camera, as described in Kong et al. (2017). Other method involves installation of sensors in the wall during its production or conservation works, as presented by Marino, Muńoz and Thomas (2017).

Influence of evaporation and wind speed to the thermal transmittance were considered by Cui et al. (2019). Results indicated that there is a function expression between thermal transmittance and wind speed and it was validated to be reliable. Authors also compared thermal transmittance with the radiation heat transfer coefficients and the thermal transmittance had a wider changing range, owing to rainfall effects. Gayo, De Frutos, Palomo and Massa (1996) considered humidity in different building materials. Research shows that the porosity is the most important feature which increases level of humidity inside the material. Świrska-Perkowska, Kucharczyk and Wyrwał (2020) analysed a numerical model of solar wall with transparent in- 
sulation. They considered different configurations of the insulation and different orientations and analysed temperature distribution for the envelopes and monthly energy balances. Yu, Cui, Shao and Han (2019) reported an influence of temperature and heat transfer in the building envelopes on the cooling and heating energy consumption and the indoor thermal and humidity environment. The results showed that humidity also should be included in thermal calculations.

The innovative technology of monitoring of the temperature, strain, humidity and loads on tested engineering objects, especially in civil engineering, uses the fiber Bragg grating (FBG) and is being developed in Department of Civil Engineering of the University of Bielsko-Biala (Juraszek, 2019a, 2019b, 2020; Juraszek \& Antonik-Popiołek, 2021).

Research can help to get to know which climate-forming factors are important in the design of an external wall. Additionally it could help to design better configuration of wall layers and materials which are used to it.

\section{MATERIAL AND METHODS}

The analysis was based on the data provided by sensors located inside the wall and a metrological station on the building.

Weather data, obtained from the main external meteorological station located on the roof of the building, as well as temperature data from the sensors in the wall, were analysed. The wall is located on the north-east side of the building. The study covered data from full month. The measuring instruments of the external weather station register data in 5-minute intervals, whereas the measurements within the wall are recorded every $15 \mathrm{~min}$. Then, the time intervals were unified and data obtained in 15-minute intervals were used for the analysis.

The wall was a cavity wall made of cellular concrete (with the density of $700 \mathrm{~kg} \cdot \mathrm{m}^{-3}$ ), insulated with expanded polystyrene and finished with face bricks. The cross-section of the wall is presented in Figure 1. The thermal transmittance equals to $\left.U=0.14 \mathrm{~W} \cdot \mathrm{m}^{-2} \cdot \mathrm{K}^{-1}\right)$.

The wall is located on the north-west side of the building, on the fifth floor. The sensors providing the data are fixed in two rows $1.6 \mathrm{~m}$ above the floor. Precise location of the sensors presents Figure 2. Data from the temperature sensors located in certain layers of the wall were used for the analysis. Information was supplied from the sensors fixed in the following locations:

- "I" half-way of the thickness of the thermal insulation,

- "II" between the thermal insulation layer and the cellular concrete wall,

- "III" half way of the thickness of the cellular concrete wall.

Based on the data obtained, the correlation between the temperatures recorded by the certain weather sensors and the speed of wind was calculated. The sample consisted of the measurements performed in January 2015 , in 15-minute intervals. The total number of the records per sensor was 2,974.

Due to sensor failures, especially in the winter period, it was impossible to collect full data in January 2016 and 2017. In this period, there was a lot of incorrect measurements or no measurements for a few hours. For this reason, the analysis was based on the most representative data of the full month in 2015 (1-31 January 2015).

Numerous errors and failed measurements can be removed by replacing the existing sensors with fiber

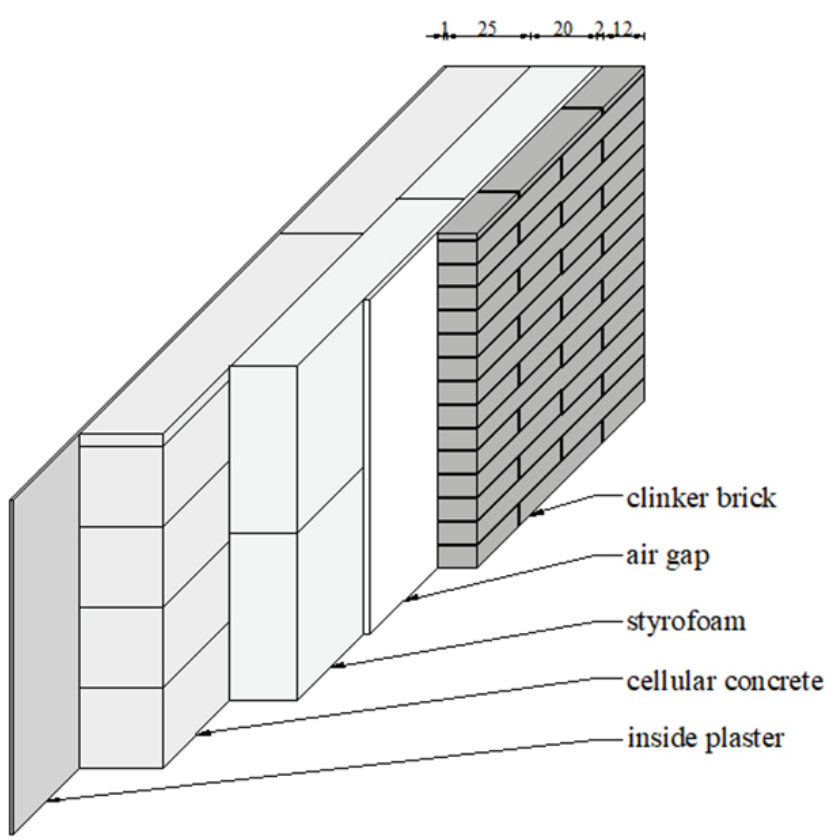

Fig. 1. Cross-section of the external wall 


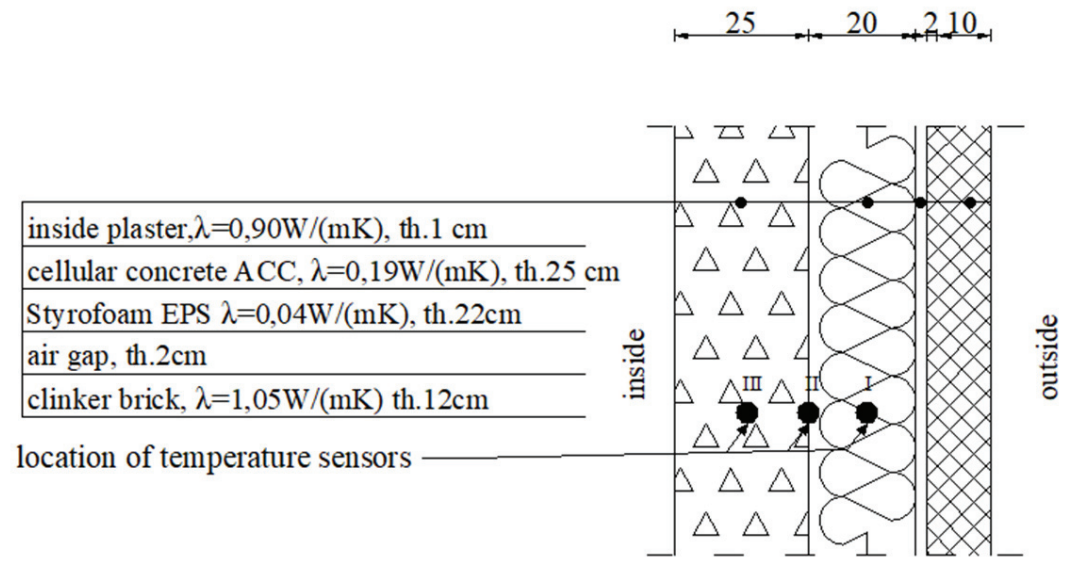

Fig. 2. Location of temperature sensors

optic devices based on Bragg's grating. Those sensors have many advantages: greater reliability, resistance to external interferences, small sizes - and they can be built into the existing structures.

Publications by Juraszek (2019a, 2019b, 2019c 2020) and Juraszek and Antonik-Popiołek (2021) present the advantages and the use of new generation of FBG and magnetic sensors.

\section{RESULTS AND DISCUSSION}

During January 2015 the temperatures were both positive and negative, between -9.5 and $17.5^{\circ} \mathrm{C}$. The solar radiation measured as illuminance was between 405 and $65,535 \mathrm{~lx}$, with the average of 2,953 lx.

The analysis was divided into three parts:

- 24-hour measurements (day and night);
- day-hour measurements (from sunrise to sunset);

- measurements including illumination above $10,000 \mathrm{~lx}$.

Table 1 presents the basic statistical characteristics of the weather factors and the temperature measured by particular sensors. Table 2 presents the basic statistical characteristics of the weather factors and the temperature measured by particular sensors only in the period from sunrise to sunset each day in January. Table 3 presents the basic statistical characteristics of the weather factors and the temperature measured by particular sensors only in the period when the solar radiation was above 10,000 lx in January 2015 .

In January the sunrise occurred between $7: 17$ and 7:39, while the sunset was between 15:47 and 16:30. Taking into account only a period between sunrise and sunset, the average illuminance was $6,982 \mathrm{~lx}$.

Table 1. Basic statistical characteristics for weather conditions and the wall temperature for 24-hour measurements (day and night)

\begin{tabular}{|c|c|c|c|c|c|}
\hline Variable & & Mean & Minimum & Maximum & $S D$ \\
\hline External temperature $\left[{ }^{\circ} \mathrm{C}\right]$ & & 3.88 & -9.5 & 17.5 & 3.7 \\
\hline Air humidity [\%] & & 73.89 & 34.0 & 91.0 & 11.5 \\
\hline Speed of wind $\left[\mathrm{m} \cdot \mathrm{s}^{-1}\right]$ & & 0.95 & 0.2 & 7.0 & 1.1 \\
\hline Solar radiation $[\mathrm{lx}]$ & & 2953.0 & 405.0 & 65535.0 & 8276.4 \\
\hline \multirow{3}{*}{ Temperature inside the wall $\left[{ }^{\circ} \mathrm{C}\right]$} & Sensor III & 15.953 & 13.9650 & 17.13 & 0.769 \\
\hline & Sensor II & 15.953 & 13.9650 & 17.13 & 0.769 \\
\hline & Sensor I & 10.634 & 5.2950 & 14.24 & 1.486 \\
\hline
\end{tabular}


Antonik-Popiołek, P. (2021). Influence of solar radiation to the temperature inside a three-layer partition in winter season. Acta Sci. Pol. Architectura, 20 (2), 75-82. doi: 10.22630/ASPA.2021.20.2.16

Table 2. Basic statistical characteristics for weather conditions and the wall temperature for day-hour measurements (from sunrise to sunset)

\begin{tabular}{|c|c|c|c|c|c|}
\hline Variable & & Mean & Minimum & Maximum & $S D$ \\
\hline External temperature $\left[{ }^{\circ} \mathrm{C}\right]$ & & 4.710 & -9.0000 & 17.50 & 4.05 \\
\hline Air humidity [\%] & & 71.599 & 34.0000 & 91.00 & 13.09 \\
\hline Speed of wind $\left[\mathrm{m} \cdot \mathrm{s}^{-1}\right]$ & & 0.954 & 0.2000 & 6.40 & 1.03 \\
\hline Solar radiation $[1 \mathrm{x}]$ & & 6981.787 & 405.0000 & 65535.00 & 12257.11 \\
\hline \multirow{3}{*}{ Temperature inside the wall $\left[{ }^{\circ} \mathrm{C}\right]$} & Sensor III & 17.353 & 15.8950 & 18.28 & 0.65 \\
\hline & Sensor II & 15.925 & 13.9650 & 17.07 & 0.76 \\
\hline & Sensor I & 10.529 & 5.2950 & 14.14 & 1.41 \\
\hline
\end{tabular}

Table 3. Basic statistical characteristics for weather conditions and the wall temperature measurements in the periods with the illumination above $10,000 \mathrm{~lx}$

\begin{tabular}{lccccc}
\hline Variable & Mean & Minimum & Maximum & $S D$ \\
\hline External temperature $\left[{ }^{\circ} \mathrm{C}\right]$ & 7.76 & -1.50 & 17.50 & 5.19 \\
\hline Air humidity $[\%]$ & 56.28 & 43.00 & 74.00 & 7.65 \\
\hline Speed of wind $\left[\mathrm{m} \cdot \mathrm{s}^{-1}\right]$ & 1.13 & 0.20 & 4.70 & 1.11 \\
\hline Solar radiation $[\mathrm{Ix}]$ & & 34718.63 & 10005.00 & 65535.00 & 18360.05 \\
\hline \multirow{2}{*}{ Temperature inside the wall $\left[{ }^{\circ} \mathrm{C}\right]$} & Sensor III & 17.13 & 15.93 & 17.72 & 0.50 \\
\cline { 2 - 6 } & Sensor II & 15.73 & 14.14 & 16.46 & 0.63 \\
\cline { 2 - 6 } & Sensor I & 10.44 & 7.89 & 12.18 & 1.29 \\
\hline
\end{tabular}

Illuminance from 400 to $500 \mathrm{~lx}$ corresponds to the sunrise and sunset on a clear day. The illuminance close to $0 \mathrm{~lx}$ can be measured in undeveloped areas at night.

Due to the location of the building in the city centre, sensors recorded illuminance above $400 \mathrm{~lx}$ even at night what was caused by lighting of the area surrounding the building. Figure 3 presents the temperature distribution in the selected layers of the wall and Figure 4 and 5 present the illumination (solar radiation) in January 2015.

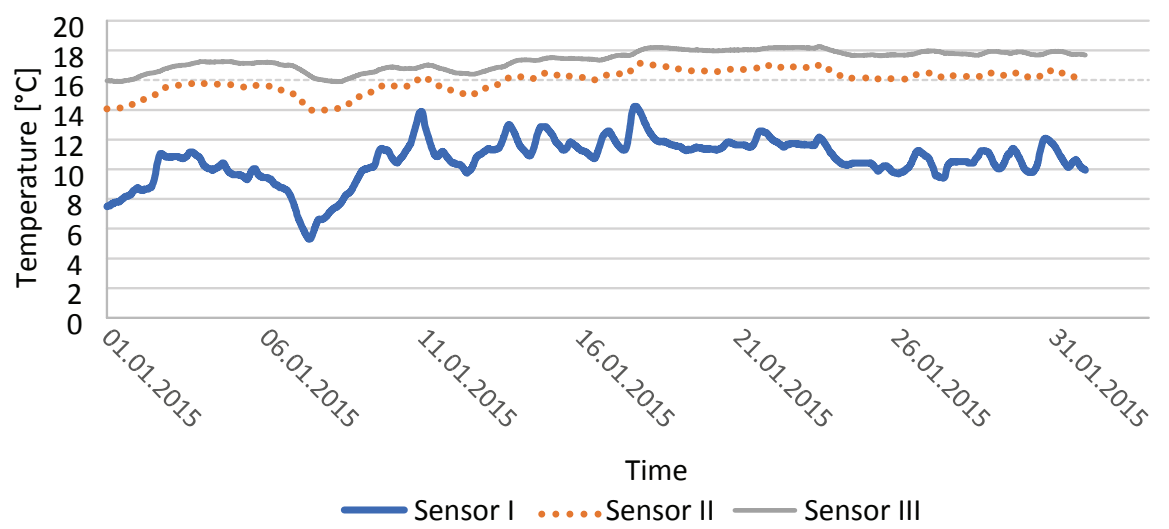

Fig. 3. Temperature inside the wall 
Antonik-Popiołek, P. (2021). Influence of solar radiation to the temperature inside a three-layer partition in winter season. Acta Sci. Pol. Architectura, 20 (2), 75-82. doi: 10.22630/ASPA.2021.20.2.16

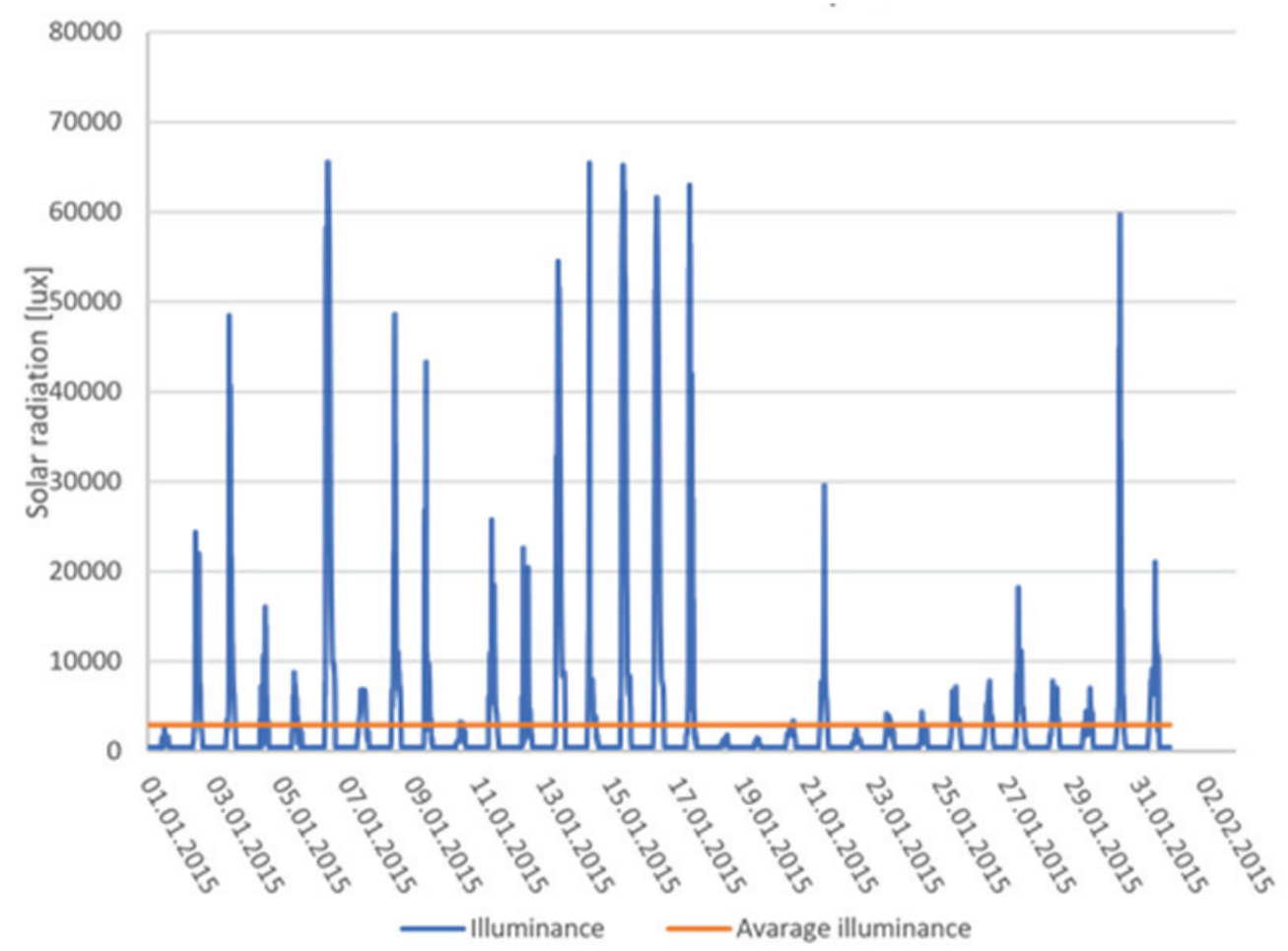

Fig. 4. Solar radiation in January 2015 (24-hour measurement)

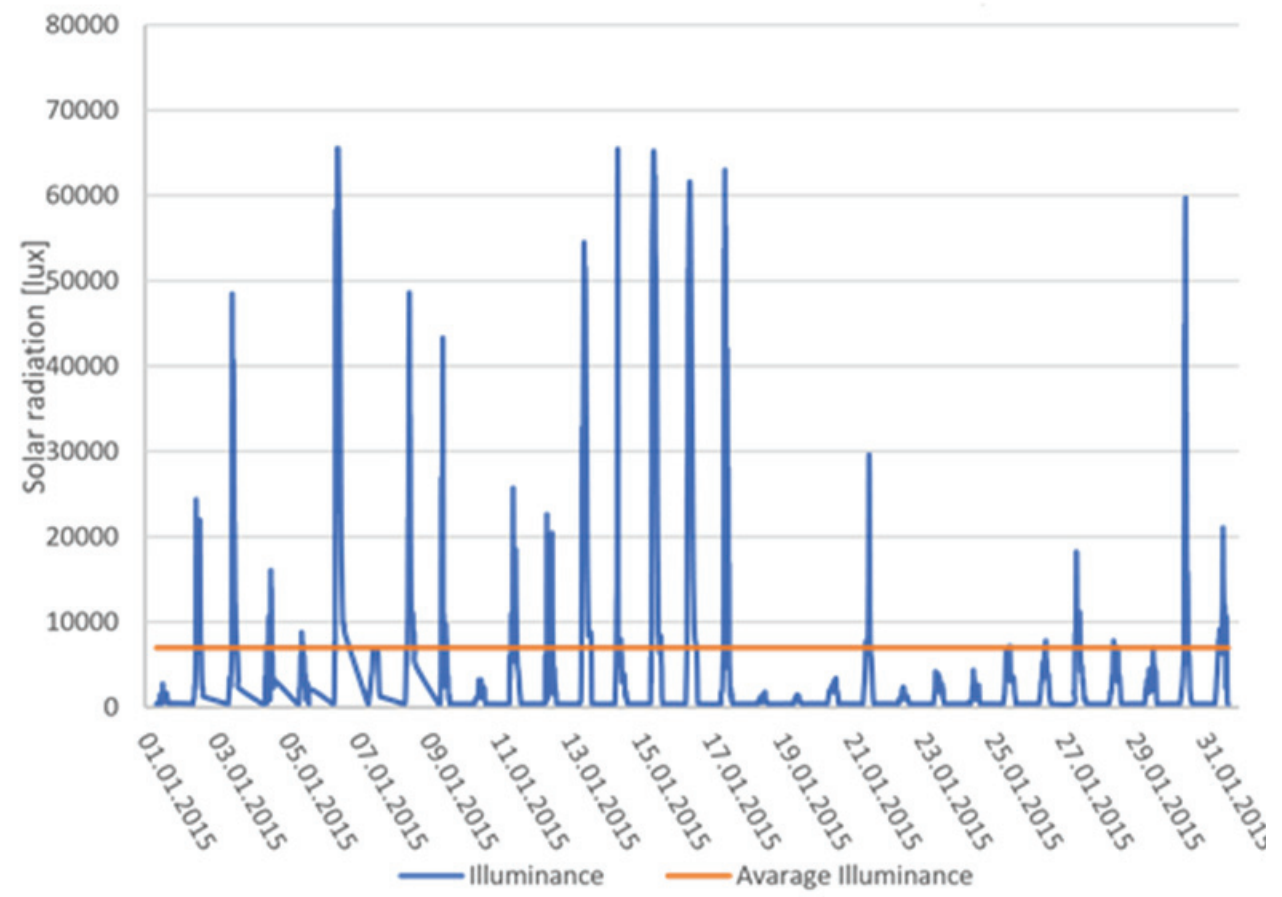

Fig. 5. Solar radiation in January 2015 at day 
Correlations were analysed between the solar radiation - illuminance and the temperature inside the wall (selected layers) as well as between solar radiation and external temperature.

The analysis was performed using MS Excel and Statistica software for Pearson's correlation, which shows the linear correlation between two variables, and the Spearman's correlation concerning any monotonic relationship, including the non-linear one, between the two variables. In both cases, a significant positive correlation means that with a growth of the value of one characteristics, there is a growth of the value of other feature. A significant negative correlation means that when one value increases, the other decreases.

The strength of the correlations and corresponding ranges of correlation coefficients are presented in Table 4. The analysis of the correlations between certain variables is presented in Tables 5-10. Tables 4 and 5 show the results of correlation analysis during one whole month, Tables 6 and 7 show the results from sunrise-to-sunset periods and Tables 8 and 9 for the periods when the solar radiation was more than $10,000 \mathrm{~lx}$.
Analysis during the whole month (Tables 5 and 6) shows that there is a weak correlation between the temperature inside the wall and the solar radiation (all three correlation coefficients show values lower than $0.3)$. Even the correlation between the outside temperature and the solar radiation is weak.

Analysis during the whole month including only day-hours (Table 7 and 8 ) also shows that there is very week correlation between the temperature inside the wall and the solar radiation (correlation coefficients lower than 0.3 ). The correlation between the outside temperature and the solar radiation is also weak.

Analysis during the periods with solar radiation greater than 10,000 lx (Table 9 and 10) shows that the correlation between the temperature inside the wall and

Table 4. Strength of correlations and their interpretation

\begin{tabular}{cc}
\hline Strength of correlation & Interpretation \\
\hline$<0.3$ & weak correlation \\
\hline$\leq 0.3-0.7$ & moderate correlation \\
\hline$\geq 0.7$ & strong correlation \\
\hline
\end{tabular}

Table 5. Pearson's correlations between solar radiation and temperature (inside the wall and external) for 24-hour measurements; correlations are significant at $p<0.05(N=2,974)$

\begin{tabular}{lllll}
\hline \multirow{2}{*}{ Variable } & \multicolumn{3}{c}{ Temperature inside the wall } & \multirow{2}{*}{ External temperature } \\
\cline { 2 - 4 } & Sensor III & Sensor II & Sensor I & 0.207004 \\
\hline Correlation coefficients & 0.065897 & 0.059411 & 0.043619 & \\
\hline
\end{tabular}

Table 6. Spearman's rank order correlations between solar radiation and temperature (inside the wall and external) for 24-hour measurements; correlations are significant at $p<0.05(N=1,131)$

\begin{tabular}{lcccc}
\hline \multirow{2}{*}{ Variable } & \multicolumn{3}{c}{ Temperature inside the wall } & \multirow{2}{*}{ External temperature } \\
\cline { 2 - 4 } & Sensor III & Sensor II & Sensor I & 0.222455 \\
\hline Correlation coefficients & 0.119425 & 0.128949 & 0.061621 & 0.25 \\
\hline
\end{tabular}

Table 7. Pearson's correlation between solar radiation and temperature (inside the wall and external); day hours only (from sunrise to sunset); correlations are significant at $p<0.05(N=1,131)$

\begin{tabular}{lcccc}
\hline \multirow{2}{*}{ Variable } & \multicolumn{3}{c}{ Temperature inside the wall } & External temperature \\
\cline { 2 - 4 } & Sensor III & Sensor II & Sensor I & 0.224269 \\
\hline Correlation coefficients & 0.111228 & 0.083658 & 0.038555 & 0 \\
\hline
\end{tabular}


Table 8. Spearman`s rank order correlations between solar radiation and temperature; day hours only (from surmise to sunset); correlations are significant at $p<0.05(N=1,131)$

\begin{tabular}{lcccc}
\hline \multirow{2}{*}{ Variable } & \multicolumn{3}{c}{ Temperature inside the wall } & \multirow{2}{*}{ External temperature } \\
\cline { 2 - 4 } & Sensor III & Sensor II & Sensor I & 0.110764 \\
\hline Correlation coefficients & 0.189246 & 0.130261 & 0.018287 & 0 \\
\hline
\end{tabular}

Table 9. Pearson's correlation between solar radiation and temperature (inside the wall and external) at solar radiation greater than 10,000 1x; correlations are significant at $p<0.05(N=123)$

\begin{tabular}{lcccc}
\hline \multirow{2}{*}{ Variable } & \multicolumn{3}{c}{ Temperature inside the wall } & \multirow{2}{*}{ External temperature } \\
\cline { 2 - 4 } & Sensor III & Sensor II & Sensor I & \\
\hline Solar radiation & 0.224537 & 0.209426 & 0.169249 & 0.116059 \\
\hline
\end{tabular}

Table 10. Spearman's rank order correlations between solar radiation and temperature (inside the wall and external) at solar radiation greater than $10,000 \mathrm{~lx}$; correlations are significant at $p<0.05(N=1,131)$

\begin{tabular}{lllll}
\hline \multirow{2}{*}{ Variable } & \multicolumn{3}{c}{ Temperature inside the wall } & \multirow{2}{*}{ External temperature } \\
\cline { 2 - 4 } & Sensor III & Sensor II & Sensor I & 0.217422 \\
\hline Solar radiation & 0.229177 & 0.226831 & 0.157319 & \\
\hline
\end{tabular}

the solar radiation is higher than in previous analyses (Tables 5-8), but it is still weak (correlation coefficients lower than 0.3 ). The correlation between the outside temperature and the solar radiation is also very weak.

Results can be different when we analyse different sides of the building. Such analysis can be done for other climate-forming factors. It could be useful to decide which factors are important and which does not matter while designing an external wall.

There is one limitation of analysis. The location of the building in the city centre may distort results a little.

\section{CONCLUSIONS}

The solar radiation does not affect the temperature recorded by sensors located in the wall. The analysis of the effect of solar radiation on the temperature in the external wall during winter leads to the following conclusions:

- there is a very weak correlation between the solar radiation and the temperature inside the wall,
- one can observe that during the periods when the solar radiation was higher, that is, more than $10,000 \mathrm{~lx}$ (up to $65,535 \mathrm{~lx}$, average 34,617 1x), the strength of correlation between the variables grows, but is still weak;

- the greater illumination does not increase the temperature inside the wall;

- no correlation can be affected by the location of the wall and the location of the weather station (north-east wall) - if one analysed the correlation between the weather conditions measured on the different walls and during other seasons the results could be different - the research will be continued;

- there are numerous errors and failed measurements while using classical temperature sensors. Errors can be removed by replacing the existing traditional sensors with fiber optic devices based on Bragg's grating which are more reliable and durable;

- there is no reason to use materials which are more solar radiation resistant or solar radiation absorbing because the correlation is to week on north and east sides of the building in the winter season. 


\section{REFERENCES}

Ahola, S. \& Lahdensivu, J. (2017). Long term monitoring of repaired external wall assembly. Energy Procedia, 132, 375-380.

Cui, Y., Xie, J., Liu, J., \& Xue, P. (2019). Experimental and Theoretical Study on the Heat Transfer Coefficients of Building External Surfaces in the Tropical Island Region. Applied Sciences, 9, 1063. https://doi.org/10.3390/ app9061063

Gayo, E., Frutos, J. De, Palomo, A. \& Massa, S. (1996). A mathematical model simulating the evaporation processes in building materials: Experimental checking through infrared thermography. Building and Environment, 31 (5), 469-475.

Juraszek, J. (2019a). The influence of the spatial structure of carbon fibers on the strength properties of a carbon composite. Fibres \& Textiles in Eastern Europe, 27 (3), 111-117.

Juraszek, J. (2019b). Residual Magnetic Field for Identification of Damage in Steel Wire Rope. Archives of Mining Science, 64 (1), 79-92.

Juraszek, J. (2019c). Residual Magnetic Field Non-destructive Testing of Gantry Cranes. Materials, 12 (4), 564. https://doi.org/10.3390/ma12040564
Juraszek, J. (2020). Fiber Bragg sensors on strain analysis of power transmission lines. Materials, 13 (7), 1559. https://doi.org/10.3390/ma13071559

Juraszek, J. \& Antonik-Popiołek, P. (2021). Fibre optic FBG sensors for monitoring of the temperature of the building envelope. Materials, 14 (5), 1207. https://doi. org/10.3390/ma14051207

Kong, Q., He, X., Cao, Y., Sun, Y., Chen, K. \& Feng, J. (2017). Numerical Analysis of the Dynamic Heat Transfer through an External Wall under Different Outside Temperatures. Energy Procedia, 105, 2818-2824.

Marino, B. M., Muńoz, N. \& Thomas, L. P. (2018). Calculation of the external surface temperature of a multi-layer wall considering solar radiation effects. Energy \& Buildings, 174, 452-463.

Świrska-Perkowska, J., Kucharczyk, A. \& Wyrwał, J. (2020). Energy Efficiency of a Solar Wall with Transparent Insulation in Polish Climatic Conditions. Energies, 13(4), 859.https://www.mdpi.com/1996-1073/13/4/859/ pdf

Yu, S., Cui, Y., Shao, Y. \& Han, F. (2019). Simulation Research on the Effect of Coupled Heat and Moisture Transfer on the Energy Consumption and Indoor Environment of Public Buildings. Energies, 12 (1), 141. https://doi.org/10.3390/en12010141

\section{WPŁYW PROMIENIOWANIA SŁONECZNEGO NA TEMPERATURĘ WEWNĄTRZ PRZEGRODY TRÓJWARSTWOWEJ W OKRESIE ZIMOWYM}

\section{STRESZCZENIE}

Artykuł przedstawia analizę wpływu promieniowania słonecznego na temperaturę w zewnętrznej przegrodzie trójwarstwowej w budynku inteligentnym. Dane do analizy pobrano z czujników temperaturowych zlokalizowanych w poszczególnych warstwach przegrody oraz ze stacji pogodowej zlokalizowanej na dachu budynku. Dane są rejestrowane 24 h w 5- i 15-minutowych odstępach. Okresem do analizy objęto jeden miesiąc w sezonie zimowym. Celem analiz było określenie korelacji między promieniowaniem słonecznym mierzonym jako natężenie promieniowania świetlnego i temperaturą wewnątrz przegrody. $\mathrm{W}$ analizowanym okresie korelacja wystąpiła, ale była bardzo słaba. Kiedy uwzględniono natężenie promieniowania świetlnego na poziomie powyżej 10000 lx, korelacja była zauważalna, jednak nadal na bardzo niskim poziomie. W trakcie badań zaproponowano wykorzystanie technologii z zastosowaniem siatki Bragga, które pozwoliłoby na uniknięcie błędnych pomiarów.

Słowa kluczowe: przegroda zewnętrzna, promieniowanie słoneczne, temperatura, budynek inteligentny 